\title{
Role model: Kay Mohanna
}

Kay Mohanna, professor of values based healthcare education at the University of Worcester, helps doctors to achieve more than they think they can

\section{Francesca Robinson}

Hampshire, UK

As an educational supervisor in the West Midlands Deanery and a GP partner and trainer at the Darwin Medical Practice in Lichfield, Kay Mohanna is involved in mentoring future GPs. She says she fell into medical education by chance. Early on in her career she was leading a research project and was asked to teach epidemiology. Working with Ruth Chambers at Staffordshire University, Mohanna then decided she would improve her skills by studying for a postgraduate teaching diploma. "Ruth was generous and supportive. In many ways I'm trying to follow the example she set-of being ambitious for others," she says.

Mohanna's interest in medical education flourished and she continued her academic career, writing numerous books and papers on teaching and training. It is, however, her international education work that she describes as the golden thread running through her career.

Mohanna is particularly proud of a fellowship programme she has set up at the University of Worcester to enable Sri Lankan trainees to come to the UK for a year. She says this is especially important for a country where general practice is not highly valued.

As a mentor, Mohanna sees her role as providing a positive and safe environment in which trainees can learn. "Developing the potential of trainees is about removing blocks and facilitating avenues for them to develop and gain self-esteem," she says. "It's about encouraging and supporting them to achieve little successes that will boost their confidence to help them to go on and achieve more."

Mohanna is currently interested in the idea of "belongingness" to encourage motivation and learning. "This is about how you create environments that offer support and challenge, and that are welcoming," she explains. "This is particularly important for GP trainees because most of them rotate through specialties in secondary care before they settle into general practice. It also applies to international trainees who come to the UK and trainees who switch into GP training from other specialties."

She adds, "It's about treating people as individuals and enabling them to recognise how their own strengths can make a contribution to practice. It's important to create an environment where they can be supported and flourish, and also, perhaps, make mistakes that they can learn from."

\section{Nominated by Raj Singavarapu}

Professor Mohanna is a wonderful person to be around. Her teaching of reflective skills in clinical practice has changed my outlook on the world of patient care in general practice.

As a mentor she motivates and infuses trainees with her infectious enthusiasm, in addition to teaching them the nuances of day-to-day practice. Her empathy, compassion, and patience are immeasurable.

It would be difficult to keep count of the number of patients and trainees who have admired and appreciated her for the difference she has made in their lives.

Raj Singavarapu is a GP registrar on the Burton Vocational Training Scheme, West Midlands Deanery.

To nominate someone who has been a role model during your medical career, send their name, job title, and the reason for your nomination to arimmer@bmj.com Published by the BMJ Publishing Group Limited. For permission to use (where not already granted under a licence) please go to http://group.bmj.com/group/rights-licensing/ permissions 